\title{
THE CEPHALIN-CHOLESTEROL FLOCCULATION TEST AS AN AID IN THE DIAGNOSIS OF HEPATIC DISORDERS ${ }^{1}$
}

\author{
By FREDERICK J. POHLE AND JOHN K. STEWART
}

(From the Departments of Medicine and Clinical Pathology, University of Wisconsin Medical School, Madison)

(Received for publication October 23, 1940)

Clinically, it is difficult and often impossible to diagnose accurately the type of hepatic or biliary tract disorder in a jaundiced individual. The determination of the prognosis in these patients is likewise difficult. It is in this particular field that the available laboratory aids are least satisfactory. The lack of simple, sensitive, and yet specific methods for measuring the multiple functions attributed to the liver has notably contributed to the problem.

Recent investigations by Hanger $(1,2)$ indicate that emulsions prepared from mixtures of sheep brain cephalin and cholesterol are flocculated by serum from jaundiced patients with active disturbances of the liver parenchyma. This serological reaction was used to differentiate hepatogenous from obstructive jaundice, since it was positive in the former and negative in the latter type. Hanger concluded that the test was more sensitive in the detection of liver disturbances than the commonly employed functional tests. Serial determinations proved to be of aid in estimating the degree and persistence of the disorder. Although the mechanism of the cephalin-cholesterol flocculation reaction is not clearly understood, Hanger (2) suggests that it depends upon the capacity of an altered serum globulin to become affixed to the colloidal elements of the emulsion.

The purpose of the present investigation was to observe the cephalin-cholesterol flocculation reaction with sera from patients having a variety of hepatic and biliary tract disorders, and to compare these results with the clinical course and other laboratory data.

\section{METHODS}

Preparation of stock solution. The cephalin employed in the preparation of the stock reagent was prepared from fresh sheep brains in the manner outlined by Chargaff (3), except that the acetone extraction was carried

1 This study was aided in part by a grant from the Wisconsin Alumni Research Foundation. out 6 times instead of 3 to assure thorough dehydration. Approximately $750 \mathrm{mgm}$. of desiccated material rich in cephalin was obtained from a sheep brain of average size. The dehydrated material was immediately mixed with cholesterol and the stock ether solution prepared exactly as previously described (2). This reagent can be kept without deterioration in a glass-stoppered bottle in an ice box at $5^{\circ} \mathrm{C}$. for at least one year.

Technique for flocculation test. The cephalin-cholesterol test was performed in the manner described elsewhere (2). One cc. of the stock ether solution is slowly added with stirring to $35 \mathrm{cc}$. of distilled water. The mixture is warmed to from 65 to $70^{\circ} \mathrm{C}$., slowly heated to boiling, and then permitted to simmer until the final volume is reduced to exactly $30 \mathrm{cc}$. All traces of ether are removed in this manner. After cooling to room temperature, $1 \mathrm{cc}$. of the milky, translucent emulsion is added to a centrifuge tube containing $0.2 \mathrm{cc}$. of the patient's serum and $4 \mathrm{cc}$. of freshly prepared 0.85 per cent sodium chloride solution. The mixture is thoroughly shaken, the tube stoppered with cotton, placed upright in a rack, and allowed to stand undisturbed at room temperature for 24 hours. At the end of this period notation as to the presence or absence of flocculation is made. With normal human sera the emulsion persists as a stable homogeneous suspension. Pathological serum flocculates the lipoid material which tends to settle to the bottom of the tube. The positive reactions are graded,+++ , +++ , or ++++ , depending on the amount of precipitation and clearing in the upper portion of the suspension. As previously reported (2), few precautions are necessary. The present observations indicate that the serum should not be drawn more than 6 hours prior to the performance of the test.

Material studied. Sera from 284 normal individuals, from 455 patients without evidence of liver or biliary tract disease, and from 141 patients with proven liver or biliary tract disease were studied in the manner described. All but 5 of the patients were adults. Each patient in the latter 2 groups was hopitalized throughout the period of observation; the average period of observation was 12.8 days. The cephalin-cholesterol flocculation test was performed at least twice a week on each of the patients. A control test was done on a normal serum on every occasion.

The diagnosis was established in many of the $141 \mathrm{pa}-$ tients with liver or biliary tract disease by histopathological studies. In the remainder of the cases the diagnosis depended upon the clinical findings and course, and the laboratory data. Abdominal surgery was done on 72 
patients and in 14 instances a section of the liver was obtained for biopsy. Complete autopsy was performed on 32 of the 40 patients with liver or biliary tract disease who died. Blood, urine, and stool examinations were done routinely. The urobilinogen in the urine of all jaundiced patients was determined quantitatively on repeated occasions. The icterus index and plasma prothrombin (4) were determined each time that a flocculation test was done. The serum albumin and globulin were measured at least once in 88 of the 141 patients with liver or biliary tract disease. Additionally, the galactose tolerance test and the hippuric acid synthesis and excretion test were frequently employed.

\section{RESULTS}

Flocculation test in normal individuals or patients without evidence of liver or biliary tract disease. The flocculation reaction was tested on sera obtained from 284 normal individuals and in no instance did significant flocculation occur. The test was also performed on the sera from $455 \mathrm{pa}$ tients with a variety of diseases, none of whom showed definite evidence of a liver or biliary tract disturbance. In this latter group a positive reac- tion was noted in 15 individuals. The diagnoses in these 15 cases were as follows: central nervous system syphilis under treatment with malaria (3 cases), pneumonia ( 2 cases), thyrotoxicosis (2 cases), and one case each of pelvic inflammatory disease, nephrosis, pyelonephritis, septic arthritis, scarlet fever, acute tertian malaria, pemphigus, and paroxysmal nocturnal hemoglobinuria. In several of these 15 patients there might well have been an associated liver disturbance but confirmatory data were lacking.

The remainder of this communication will be limited to a report of the observations on the group of 141 patients with hepatic or biliary tract disease. For convenience in obtaining a comparative analysis, these cases have been divided into 5 groups, as follows: (1) cholecystitis without hepatic disease, (2) acute or subacute hepatitis, (3) cirrhosis of the liver, (4) obstructive jaundice, and (5) focal lesions of the liver.

Flocculation reaction in cholecystitis without hepatic disease. Thirty-four patients with chronic

TABLE I

Flocculation reaction in 36 patients with acute or subacute hepatitis

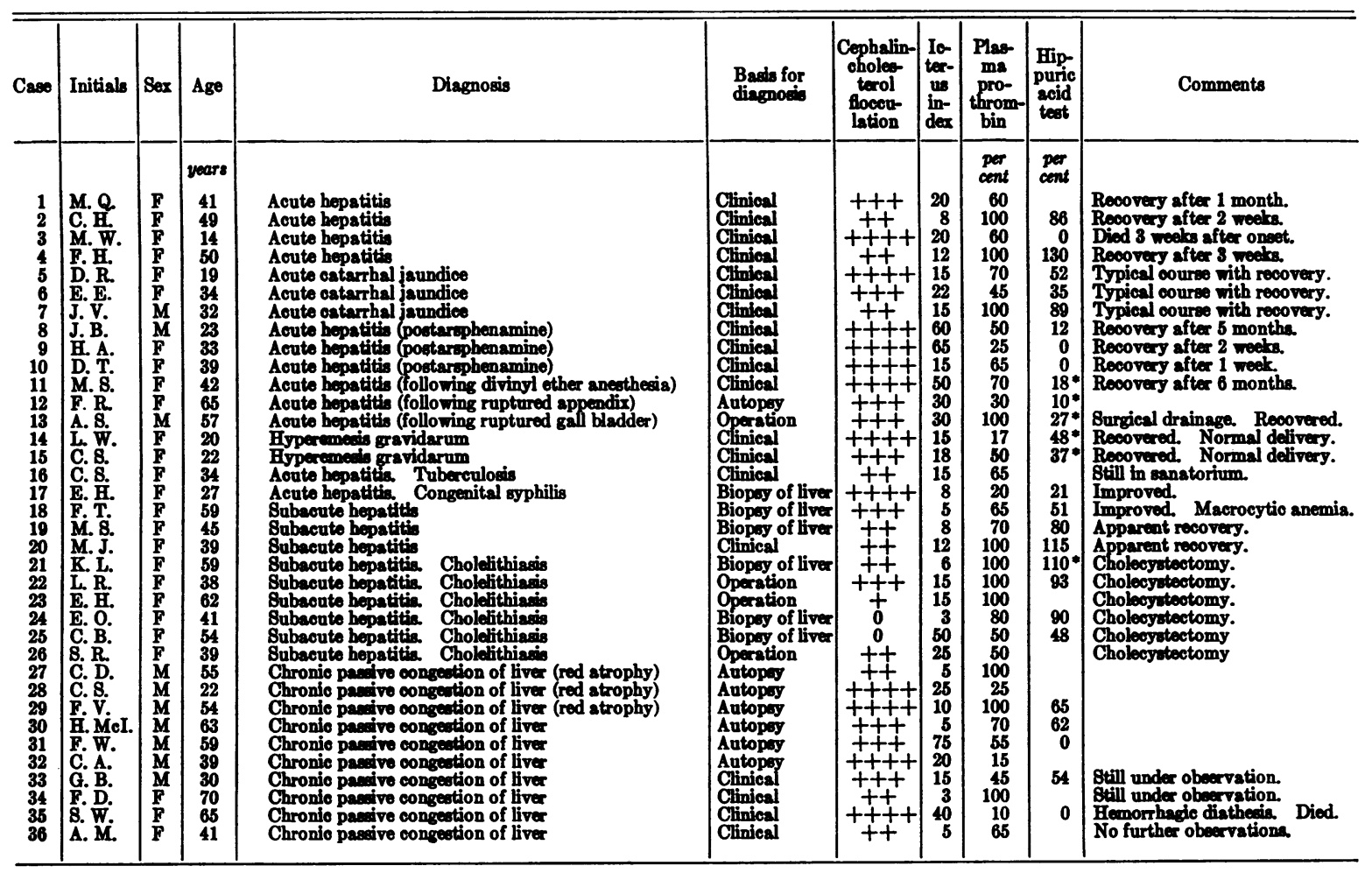

* Denotes intravenous administration of sodium benzoate. 
TABLE II

Changes in the cephalin-cholesterol flocculation reaction and other laboratory data during the course of an acute toxic hepatitis (Case 1, Table $I$ )

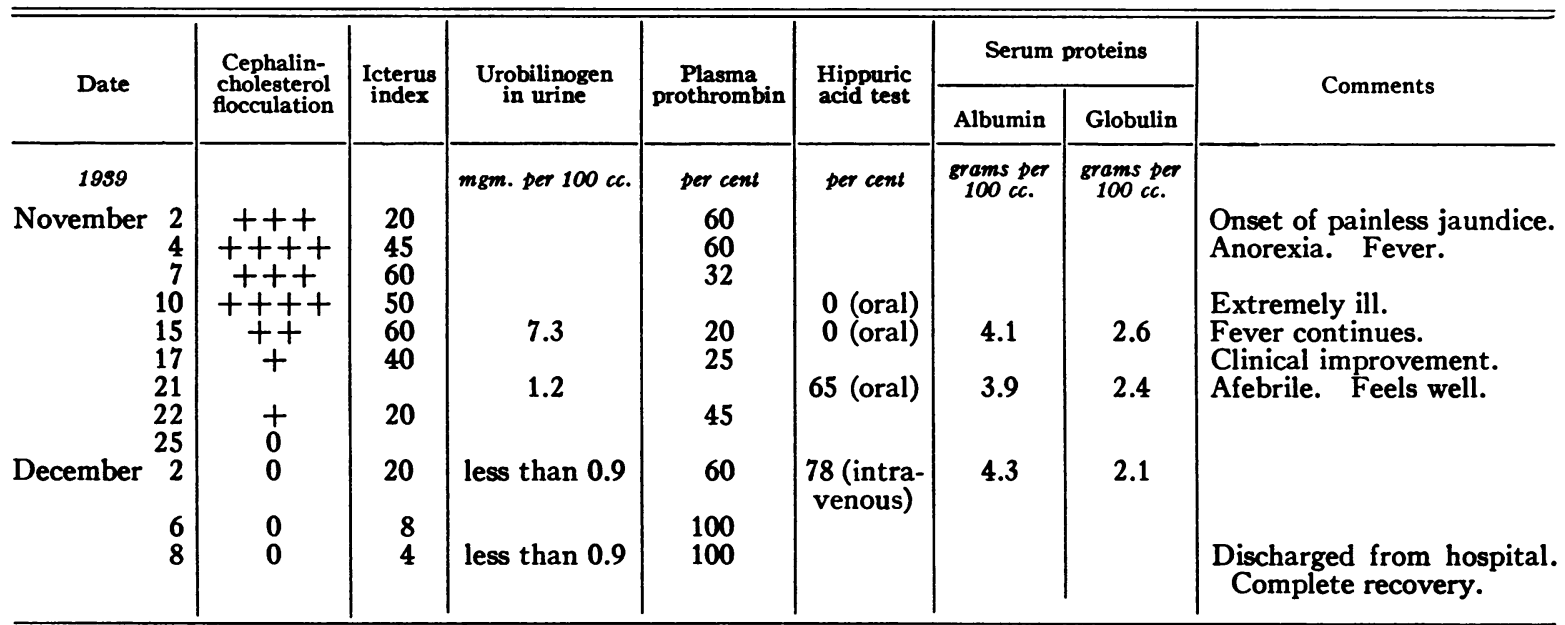

cholecystitis with or without cholelithiasis and without liver complications were studied. The flocculation was negative in all except 3 . The amount of flocculation in each of these 3 patients was slight $(+,+$, and ++$)$. All had stones in the gall bladder, but it was not possible to demonstrate liver pathology, even though sections from 2 patients were available for microscopic study. Surgery was performed on the gall bladder in 30 of the 34 subjects.

Flocculation reaction in patients with acute or subacute hepatitis. Observations were made on 36 patients with hepatitis of an acute or subacute form. There was no evidence of obstruction of the biliary passages in any of these individuals. The diagnosis was established in 12 patients after histological examination of liver tissue. A reduction in plasma prothrombin was observed in 25 of these 36 patients. This observation furnished further evidence that significant liver damage was present (5). Table I presents the diagnosis, the basis for the diagnosis, the cephalin-cholesterol flocculation reaction, icterus index, plasma prothrombin, and the hippuric acid excretion in these patients. The data were collected at the time the diagnosis was established. The cephalin-cholesterol flocculation test was positive in all but 2 of the 36 cases.

Although chronic passive congestion of the liver is not an inflammatory lesion, Cases 26 to 36, inclusive (Table I), are classified with this group because of the extensive parenchymal destruction. In contrast to these 11 patients with a positive flocculation test, it should be noted that sera from 18 other patients with congestive cardiac failure and similar clinical signs of congestion of the liver, not included in Table I, showed no flocculation.

Repeated observations were made on all of the 36 patients with acute or subacute hepatitis during the course of their disease. A close correlation was usually demonstrated between the amount of flocculation and the clinical severity of the disorder. In each of the individuals who recovered, the positive reaction gradually became weaker, and finally negative as clinical improvement was noted. Table II presents data on a case typical of this group. These observations are in agreement with Hanger's (2) suggestion that the flocculation test has considerable prognostic value.

Flocculation reaction in patients with cirrhosis of the liver. Twenty-two patients with various types of cirrhosis of the liver were studied. In most of these individuals the disease was in the terminal stage. Table III gives the diagnosis, the basis for the diagnosis, the cephalin-cholesterol flocculation reaction, icterus index, per cent of plasma prothrombin, and the results of the hippuric acid test. In addition, the serum albumin was reduced, and the globulin abnormally elevated in 17 patients. Table III shows that the flocculation test was uniformly strongly, positive in this group of patients. Serial studies showed a 
TABLE III

Flocculation reaction in 22 patients with cirrhosis of the liver

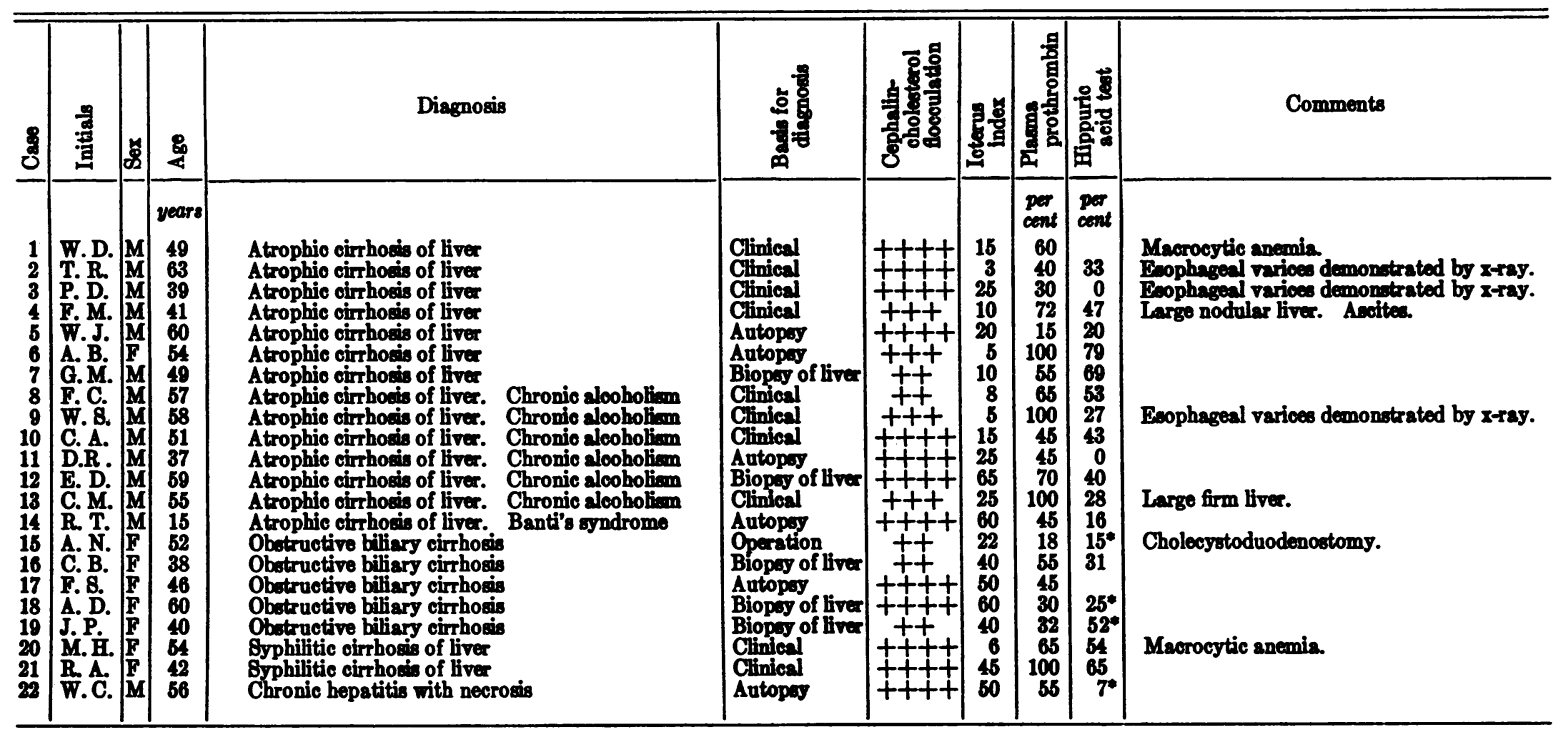

* Denotes intravenous administration of sodium benzoate.

persistence of the reaction throughout the period of observation. The abnormal hippuric acid test in 18 of these patients, and the prothrombin deficiency in 18, further support the evidence of extensive liver damage. All of the patients with hypoprothrombinemia failed to show a significant increase in this coagulation factor with prolonged administration of crude concentrates of vitamin $\mathrm{K}$ or 2-methyl-1, 4-naphthoquinone. ${ }^{2}$ The lack of response of the prothrombin to this therapy also indicates an impairment of liver function (5).

Flocculation reaction in patients with obstructive jaundice. Observations were made on 23 jaundiced patients who had complete obstruction of the extrahepatic biliary passages. Table IV shows the cause of the obstruction, basis for the diagnosis, approximate duration of the icterus, cephalin-cholesterol flocculation, icterus index, plasma prothrombin, and the hippuric acid test. The data presented in this table were obtained at the time of the patient's admission to the hospital. In addition, the urobilinogen in the urine was less than $0.9 \mathrm{mgm}$. per $100 \mathrm{cc}$. in each patient. The flocculation test was positive in 18 of the 23 patients in this group. These results are not in agreement with previous reports $(1,2,6)$ which indicate that flocculation does not occur with sera

\footnotetext{
${ }^{2}$ Supplied through the courtesy of E. R. Squibb and Sons, New York.
}

from patients with biliary obstruction. Comparison of the flocculation reactions of the subjects in Tables I, III, and IV does show, however, that the degree of flocculation was less in the individuals with obstructive jaundice than in those with hepatitis.

The data in Table IV show that the plasma prothrombin was reduced in every patient, and that in a majority the deficiency was marked. Cases 5 and 17 showed hemorrhagic manifestations. The response of the prothrombin to treatment with preparations with vitamin $\mathrm{K}$ activity was satisfactory with the exception of Cases 1 , 14, 21, and 23. An obstructive biliary cirrhosis or hepatitis was demonstrated histologically in these 4 patients. In addition, a secondary disturbance in the liver was suspected by the surgeon at the time of operation in Cases 5, 19, and 20.

Flocculation reaction in patients with focal lesions of the liver. Hanger (2) reported that single or disseminated carcinomatous lesions in the liver were usually accompanied by a negative cephalin-cholesterol flocculation test, although it was recognized that the series was too small to make a definite conclusion. In the present study observations were made on 26 patients with focal lesions of the liver. The group was composed of cases with a variety of lesions which either replaced or invaded liver tissue. Table $\mathrm{V}$ presents 
TABLE IV

Flocculation reaction in 23 patients with obstructive jaundice

\begin{tabular}{|c|c|c|c|c|c|c|c|c|c|c|c|}
\hline Caso & Initials & Sex & Age & Diagnosis & $\begin{array}{c}\text { Basis } \\
\text { for } \\
\text { diagnosis }\end{array}$ & $\begin{array}{c}\text { Approxi- } \\
\text { mate } \\
\text { duration } \\
\text { of } \\
\text { jaundice }\end{array}$ & $\begin{array}{l}\text { Cephe- } \\
\text { lin-obo- } \\
\text { lesterol } \\
\text { flocen- } \\
\text { letion }\end{array}$ & $\begin{array}{l}\text { Ioterns } \\
\text { index }\end{array}$ & $\begin{array}{c}\text { Plams } \\
\text { pro- } \\
\text { throm- } \\
\text { bin }\end{array}$ & $\underset{\substack{\text { Fip- } \\
\text { purio } \\
\text { acid teat }}}{ }$ & Comments \\
\hline $\begin{array}{l}1 \\
2 \\
3 \\
4 \\
5 \\
6 \\
7 \\
8 \\
9 \\
10 \\
11 \\
12 \\
13 \\
14 \\
15 \\
16 \\
17 \\
18 \\
19 \\
20 \\
21 \\
22\end{array}$ & $\begin{array}{l}\text { S. S. } \\
\text { W. H. } \\
\text { W. } .8 . \\
\text { E. M. } \\
\text { R. L. } \\
\text { B. E. } \\
\text { C. V. } \\
\text { B. F. } \\
\text { L. S. } \\
\text { R. R. } \\
\text { H. G. } \\
\text { J. P. } \\
\text { J. D. } \\
\text { F. D. } \\
\text { W. W. } \\
\text { S. G. } \\
\text { H. K. } \\
\text { A. S. } \\
\text { C. B. } \\
\text { M. B. } \\
\text { E. B. } \\
\text { E. N. } \\
\text { S. D. }\end{array}$ & $\begin{array}{l}\mathbf{F} \\
\mathbf{M} \\
\mathbf{M} \\
\mathbf{M} \\
\mathbf{M} \\
\mathbf{F} \\
\mathbf{M} \\
\mathbf{M} \\
\mathbf{F} \\
\mathbf{M} \\
\mathbf{M} \\
\mathbf{M} \\
\mathbf{M} \\
\mathbf{M} \\
\mathbf{M} \\
\mathbf{M} \\
\mathbf{M} \\
\mathbf{F} \\
\mathbf{F} \\
\mathbf{F} \\
\mathbf{M} \\
\mathbf{F}\end{array}$ & \begin{tabular}{|c} 
your \\
46 \\
65 \\
57 \\
58 \\
44 \\
42 \\
50 \\
53 \\
25 \\
41 \\
50 \\
48 \\
62 \\
53 \\
45 \\
60 \\
55 \\
59 \\
38 \\
52 \\
29 \\
61 \\
68
\end{tabular} & $\begin{array}{l}\text { Stone in common bile duct } \\
\text { Stone in common bile duct } \\
\text { Stone in common bile duct } \\
\text { Stone in common bile duct } \\
\text { Stones in common bile duot } \\
\text { Stones in common bile duct } \\
\text { Stones in common bile duot } \\
\text { Stones in oommon bile duct } \\
\text { Stones in common bile duct } \\
\text { Stones in common bile duot } \\
\text { Stone in common bile duct (ball valve) } \\
\text { Carcinoms of head of pancreas } \\
\text { Carcinoma of head of pancreas } \\
\text { Carcinoms of head of pancreas } \\
\text { Carcinoms of head of pancreas } \\
\text { Carcinoma of head of pancreas } \\
\text { Carcinoma of head of pancreas } \\
\text { Carcinoma of head of pancreas } \\
\text { Adhesions about common bile duot } \\
\text { Adhesions about oommon bile duct } \\
\text { Stricture of oommon bile duct } \\
\text { Obotruction of common bile duct due } \\
\text { to lymph node } \\
\text { Carcinoms of gall bladder }\end{array}$ & $\begin{array}{l}\text { Autopey } \\
\text { Operation } \\
\text { Clinical } \\
\text { Operation } \\
\text { Operation } \\
\text { Operation } \\
\text { Operation } \\
\text { Operation } \\
\text { Operation } \\
\text { Operation } \\
\text { Operation } \\
\text { Operation } \\
\text { Cinical } \\
\text { Autopey } \\
\text { Operation } \\
\text { Operation } \\
\text { Operation } \\
\text { Clinical } \\
\text { Operation } \\
\text { Operation } \\
\text { Autopey } \\
\text { Operation } \\
\text { Antopes }\end{array}$ & \begin{tabular}{|c}
2 \\
2 woeks \\
2 months \\
3 weeks \\
2 months \\
10 months \\
1 week \\
3 months \\
2 weeks \\
5 \\
3 weeks \\
3 weeks \\
2 months \\
3 months \\
1 month \\
3 months \\
3 months \\
6 weeks \\
1 month \\
4 months \\
14 months \\
2 months \\
18 months \\
6 weeks \\
unkown
\end{tabular} & + & $\begin{array}{r}50 \\
50 \\
30 \\
40 \\
20 \\
50 \\
35 \\
40 \\
100 \\
60 \\
25 \\
20 \\
75 \\
60 \\
60 \\
75 \\
25 \\
80 \\
30 \\
55 \\
30 \\
100\end{array}$ & $\begin{array}{c}\text { per cent } \\
45 \\
32 \\
75 \\
75 \\
35 \\
80 \\
65 \\
40 \\
32 \\
20 \\
80 \\
45 \\
17 \\
60 \\
55 \\
28 \\
42 \\
55 \\
62 \\
35 \\
40 \\
40 \\
40\end{array}$ & \begin{tabular}{|c|} 
per cent \\
97 \\
69 \\
90 \\
112 \\
24 \\
95 \\
77 \\
84 \\
115 \\
90 \\
82 \\
54 \\
102 \\
86 \\
75 \\
60 \\
86 \\
51 \\
110 \\
83
\end{tabular} & $\begin{array}{l}\text { Post-operative evisceration. Recovered. } \\
\text { Still under obeervation. } \\
\text { Complete recovery. } \\
\text { Died of intra-abdominal hemorrhage. } \\
\text { Complete recovery. } \\
\text { Complete recovery. } \\
\text { Complete recovery. } \\
\text { Complete recovery. } \\
\text { Complete recovery. } \\
\text { Still under obeervation. } \\
\text { Still under obeervation. } \\
\text { Died. } \\
\text { Still under obeervation. } \\
\text { No follow-up. } \\
\text { Hemorrhagic diathesis. } \\
\text { Died. } \\
\text { Cholecystoduodenostomy. } \\
\text { Plastio repair of duct. Recovery. } \\
\text { Complete recovery. }\end{array}$ \\
\hline
\end{tabular}

TABLE V

Flocculation reaction in 26 patients with focal lesions of the liver

\begin{tabular}{|c|c|c|c|c|c|c|c|c|c|}
\hline Caco & Initials & Sex & Age & Dikgnodis & $\begin{array}{c}\text { Basis } \\
\text { for } \\
\text { diagnodis }\end{array}$ & $\begin{array}{l}\text { Cophalin- } \\
\text { choles- } \\
\text { terol } \\
\text { floceu- } \\
\text { lation }\end{array}$ & $\begin{array}{l}\text { Icterus } \\
\text { index }\end{array}$ & $\begin{array}{c}\text { Placm } \\
\text { pro- } \\
\text { throm- } \\
\text { bin }\end{array}$ & Comments \\
\hline $\begin{array}{r}1 \\
2 \\
3 \\
4 \\
5 \\
6 \\
7 \\
8 \\
9 \\
10 \\
11 \\
12 \\
13 \\
14 \\
15 \\
16 \\
17 \\
18 \\
19 \\
20 \\
21 \\
22 \\
23 \\
24 \\
25 \\
26\end{array}$ & 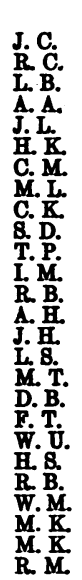 & $\begin{array}{l}\mathbf{M} \\
\mathbf{M} \\
\mathbf{M} \\
\mathbf{M} \\
\mathbf{M} \\
\mathbf{M} \\
\mathbf{M} \\
\mathbf{F} \\
\mathbf{F} \\
\mathbf{F} \\
\mathbf{M} \\
\mathbf{F} \\
\mathbf{M} \\
\mathbf{M} \\
\mathbf{M} \\
\mathbf{F} \\
\mathbf{F} \\
\mathbf{M} \\
\mathbf{M} \\
\mathbf{M} \\
\mathbf{M} \\
\mathbf{M} \\
\mathbf{M} \\
\mathbf{F} \\
\mathbf{F} \\
\mathbf{F}\end{array}$ & $\begin{array}{c}\text { years } \\
64 \\
50 \\
70 \\
54 \\
73 \\
58 \\
67 \\
64 \\
11 \\
68 \\
78 \\
65 \\
67 \\
10 \\
3 \\
54 \\
65 \\
12 \\
58 \\
38 \\
29 \\
33 \\
11 \\
9 \\
29 \\
55\end{array}$ & 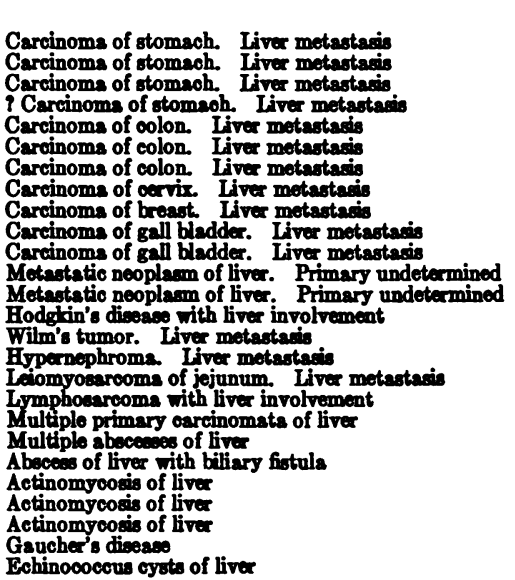 & $\begin{array}{l}\text { Autopey } \\
\text { Antopey } \\
\text { Clinical } \\
\text { Clinical } \\
\text { Operation } \\
\text { Operation } \\
\text { Biopey of live } \\
\text { Cinical } \\
\text { Autopey } \\
\text { Autopey } \\
\text { Operation } \\
\text { Clinical } \\
\text { Clinical } \\
\text { Autopey } \\
\text { Antopsy } \\
\text { Biopey of live } \\
\text { Autopey } \\
\text { Autopey } \\
\text { Autopsy } \\
\text { Operation } \\
\text { Autopey } \\
\text { Autopey } \\
\text { Biopey of live } \\
\text { Autopgy } \\
\text { Operation } \\
\text { Autopey }\end{array}$ & & $\begin{array}{r}22 \\
20 \\
20 \\
40 \\
3 \\
3 \\
20 \\
10 \\
3 \\
8 \\
8 \\
75 \\
13 \\
15 \\
10 \\
100 \\
3 \\
12 \\
10 \\
100 \\
5 \\
75 \\
4 \\
15 \\
5 \\
5 \\
\mathbf{3 5}\end{array}$ & $\begin{array}{c}\text { per cent } \\
52 \\
32 \\
70 \\
40 \\
50 \\
100 \\
80 \\
22 \\
60 \\
40 \\
65 \\
70 \\
47 \\
100 \\
100 \\
60 \\
100 \\
100 \\
60 \\
55 \\
28 \\
55 \\
45 \\
70 \\
65 \\
100\end{array}$ & $\begin{array}{l}\text { Gartio malignanoy by x-ray. } \\
\text { Nodular liver. } \\
\text { Died. } \\
\text { Large, nodular liver. } \\
\text { Large, nodular liver. } \\
\text { Intra-abdominal hemorrhage. } \\
\text { Splenectomy. }\end{array}$ \\
\hline
\end{tabular}

the diagnosis, basis for the diagnosis, cephalincholesterol test, icterus index, and plasma prothrombin in these subjects. These laboratory results were obtained shortly after admission of the patient to the hospital. Repeated tests were entirely similar. The data show that flocculation occurred in every patient except Case 9 . In most instances the reaction was strongly positive. The plasma prothrombin was reduced in 19 patients in this group, and in cases in which specific therapy was given for this deficiency there was slight, if any, improvement.

\section{SUMMARY AND DISCUSSION}

The present observations confirm original studies $(1,2)$ which indicate that emulsions prepared 
from mixtures of sheep brain cephalin and cholesterol are flocculated by sera from patients with active disturbances of the liver parenchyma. In the present investigation, sera from 880 human subjects were studied. These data are summarized in Table VI. In this table the patients are grouped in the same manner as they were earlier in this communication when more detailed observations were presented. These results indicate that the incidence of a positive flocculation reaction is very high with sera from individuals with a liver disorder and that false positive reactions rarely occur.

TABLE VI

Summary of the cephalin-cholesterol flocculation reaction on sera from 880 human subjects

\begin{tabular}{|c|c|c|c|c|}
\hline Diagnosis & 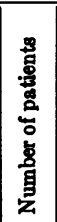 & 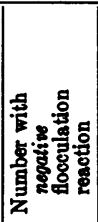 & 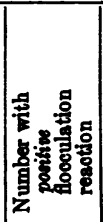 & 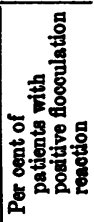 \\
\hline 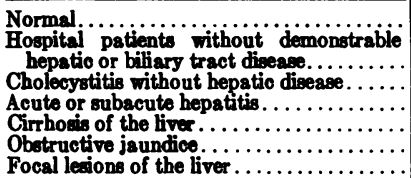 & $\begin{array}{r}284 \\
455 \\
34 \\
36 \\
22 \\
23 \\
26\end{array}$ & $\begin{array}{r}284 \\
440 \\
31 \\
2 \\
0 \\
5 \\
1\end{array}$ & $\begin{array}{r}0 \\
15 \\
3 \\
34 \\
22 \\
18 \\
25\end{array}$ & $\begin{array}{r}0 \\
3.3 \\
8.8 \\
94.4 \\
100.0 \\
78.3 \\
96.2\end{array}$ \\
\hline
\end{tabular}

The major discrepancy between the present observations and those previously reported $(1,2,6)$ resides in the cephalin-cholesterol flocculation reaction with sera from individuals with obstructive jaundice. Hanger (2) concluded that jaundice due to biliary obstruction may be distinguished from hepatogenous jaundice by the flocculation test, since the reaction was usually negative in the former and positive in the latter. In a recent publication (6) Hanger and Gutman distinguished two kinds of postarsphenamine jaundice (hepatitis and intrahepatic biliary obstruction) with the aid of the cephalin-cholesterol flocculation test. These authors noted that flocculation occurred in only 8 of 85 patients (9.4 per cent) with various types of obstructive jaundice. This value is at variance with the present study in which it was noted that flocculation occurred in 18 of 23 such patients (78.3 per cent). The explanation for this lack of agreement is not clear. It is possible that our series of 23 patients with complete biliary obstruction had a higher inci- dence of secondary disturbances in the liver than Hanger's and Gutman's series, since their group did not all have complete or constant obstruction. It is true in the present study that the test was usually less strongly positive in the patients with obstructive jaundice than in those with a hepatic disorder (Tables I, III, IV, and V). However, the observations herein reported would not permit the use of the cephalin-cholesterol flocculation test in the differential diagnosis of obstructive from hepatogenous jaundice.

There is general agreement that a common disadvantage of the liver function tests which are usually employed is their lack of sensitivity. Often such functional studies remain within normal limits until the end stage of the disorder when a diffuse and irreparable damage has already occurred. Reports by Hanger (2) indicate that the cephalin-cholesterol flocculation test is a more delicate index of active disturbances of the liver than any of the so-called liver function tests. The present investigation confirms this conclusion. The flocculation reaction with few exceptions proved to be a more sensitive indicator of a liver disorder than any of the other tests which were used. This finding is still more impressive when it is recalled that false positive reactions are extremely rare. In several cases an hepatic abnormality, the presence of which was conclusively verified later, was not suspected until the flocculation test was reported positive.

Hanger $(1,2)$ was unable to demonstrate any correlation between the degree of flocculation of the cephalin-cholesterol complex and the bromsulphalein excretion, hippuric acid formation, levulose tolerance test, Takata-Ara reaction, formol-gel test, the albumin-globulin ratio, serum phosphatase, blood cholesterol or serum bilirubin. $\mathrm{He}$ concluded that the flocculation test should be regarded as an index of disturbance of the liver parenchyma and that it did not parallel tests for hepatic function. The present observations do not agree with this statement. Although, as mentioned previously, the flocculation test was usually the most delicate index, our data show that $a++$ or stronger reaction was usually accompanied by an abnormal decrease in hippuric acid synthesis and excretion and a reduction in the plasma prothrombin. There was no correlation between these 3 laboratory procedures and the intensity 
or duration of jaundice. The serum albumin and globulin were usually abnormal when the liver damage was severe and of long duration.

The cephalin-cholesterol flocculation test, as previously described (2), is of especial value in determining the prognosis of patients with hepatitis. In a majority of individuals with acute or subacute hepatitis, the flocculation reaction decreased or became negative before the icterus receded. The data in Table II illustrate the prognostic significance of the test. We have not observed a recurrence of jaundice in any patient once the test became negative. The persistence of a strongly positive reaction, such as was noted in a few patients with subacute hepatitis and in most of those with cirrhosis or focal lesions of the liver, suggests a poor prognosis despite periods of temporary clinical improvement.

The functions of the liver are multiple and there is no universal test of hepatic function. The tests are modified by many factors such as the type and extent of the liver disease, its acute or chronic nature, the presence or absence of infection, the presence or absence of regeneration of the parenchymal cells and the amount of available protein and glycogen. White, Deutsch, and Maddock (7) have pointed out that certain tests are preferred because of their delicacy, others because of the prognostic value with serial studies. The present data indicate that the cephalincholesterol flocculation test is a sensitive and reliable index of a liver disturbance regardless of its etiology, and that it is a valuable adjunct to the other laboratory aids.

\section{CONCLUSIONS}

1. Emulsions prepared from mixtures of sheep brain cephalin and cholesterol are not flocculated by serum from normal individuals and rarely by serum from patients without hepatic disease.

2. Cephalin-cholesterol emulsions are regularly flocculated by serum from patients with hepatitis, cirrhosis of the liver or focal lesions of the liver.
3. The flocculation test is a more sensitive index of hepatic disease than many of the functional studies. A strongly positive reaction is usually accompanied by a reduction in the plasma prothrombin and hippuric acid synthesis and excretion.

4. The flocculation reaction is usually negative in gall bladder disease without hepatic complications.

5. In the present study the flocculation test was not a reliable guide for the differentiation of obstructive from hepatogenous jaundice.

6. The cephalin-cholesterol flocculation test is a valuable adjunct to other laboratory procedures in the diagnosis and prognosis of jaundiced patients.

\section{BIBLIOGRAPHY}

1. Hanger, F. M., The flocculation of cephalin-cholesterol emulsions by pathological sera. Tr. A. Am. Physicians, 1938, 53, 148.

2. Hanger, F. M., Serological differentiation of obstructive from hepatogenous jaundice by flocculation of cephalin-cholesterol emulsions. J. Clin. Invest., 1939, 18, 261.

3. Chargaff, E., Quoted by Hanger, F. M., in Serological differentiation of obstructive from hepatogenous jaundice by flocculation of cephalin-cholesterol emulsions. J. Clin. Invest., 1939, 18, 261.

4. Pohle, F. J., and Stewart, J. K., A study of the Quick method for the quantitative determination of prothrombin with suggested modifications. Am. J. M. Sc., 1939, 198, 622.

5. Pohle, F. J., and Stewart, J. K., Observations on the plasma prothrombin and the effects of vitamin $\mathrm{K}$ in patients with liver or biliary tract disease. $\mathrm{J}$. Clin. Invest., 1940, 19, 365.

6. Hanger, F. M., Jr., and Gutman, A. B., Postarsphenamine jaundice apparently due to obstruction of intrahepatic biliary tract. J. A. M. A., 1940, 115, 263.

7. White, F. W., Deutsch, E., and Maddock, S., The comparative value of serial hippuric acid excretion, total cholesterol, cholesterol ester and phospholipid tests in diseases of the liver. II. A clinical comparison of the tests. Am. J. Digest. Dis., 1940, $7,3$. 